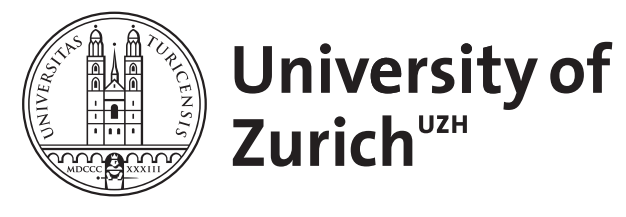

\title{
Introduction to the Human Economy
}

\author{
Bueno, Nicolas
}

\begin{abstract}
How to reduce the fear of unemployment, the risks associated with quitting an unfulfilling job or retiring earlier? Is there an economic model that could make us freer from traditional paid work and would work for all in both developing and developed countries? The discussion in this piece goes beyond the idea of a basic income. After presenting the historical origins of the right to work, influenced by the dogma of work, this piece introduces the terminology of the human economy. It questions the necessity of traditional paid work and discusses how it may be possible to achieve greater freedom from work whilst simultaneously securing a wide range of human benefits.
\end{abstract}

Posted at the Zurich Open Repository and Archive, University of Zurich

ZORA URL: https://doi.org/10.5167/uzh-199207

Scientific Publication in Electronic Form

Accepted Version

Originally published at:

Bueno, Nicolas (2018). Introduction to the Human Economy. London School of Economics: Centre for the Study of Human Rights, London School of Economics. 


\title{
Introduction to the Human Economy
}

\author{
Nicolas Bueno*
}

How to reduce the fear of unemployment, the risks associated with quitting an unfulfilling job or retiring earlier? Is there an economic model that could make us freer from traditional paid work and would work for all in both developing and developed countries? The discussion in this piece goes beyond the idea of a basic income. After presenting the historical origins of the right to work, influenced by the dogma of work, this piece introduces the terminology of the human economy. It questions the necessity of traditional paid work and discusses how it may be possible to achieve greater freedom from work whilst simultaneously securing a wide range of human benefits.

The human economy framework was originally presented in 'From the Right to Work to Freedom from Work: Introduction to the Human Economy' (International Association of Labour Law Journals Award 2017) 33(4) International Journal of Comparative Labour Law and Industrial Relations. It is also introduced in the short video 'Should we Have a New Right to Freedom from Work?' by Latest Thinking.

\section{The Right to Work Between Socialism and Capitalism}

The contemporary right to work includes the opportunity to earn a living by working and the right to freely choose and accept work. This piece puts forward the view that socialist and capitalist economic systems, which can be differentiated according to who is the main provider of work, the State or private employers, are not fully equipped to provide the economic security and freedom that people attempt to find through work. Both economic systems focus too much on how to provide enough paid work instead of looking at how to reduce society's necessity to work.

\footnotetext{
* Lecturer at the Chair of Public International Law of the University of Lausanne (Switzerland). The article 'From the Right to Work to Freedom from Work: Introduction to the Human Economy' 33(4) IJCL 463-488 was written during the affiliation as Visiting Fellow to the London School of Economics Laboratory for Advanced Research on the Global Economy from January to July 2017. Nicolas.Bueno@uzh.ch; Twitter: @NBueno_UZH. This paper has been published as N Bueno, Introduction to the Human Economy, SPEAK OUT at The Laboratory for Advanced Research on the Global Economy, Centre for the Study of Human Rights, LSE (August 2018)
} 
Historically, the right to work emerged as a socialist demand in the middle of the nineteenth century as a reaction to a new phenomenon: unemployment. In Socialisme: Droit au Travail (1848), Louis Blanc suggested that the government should guarantee work by means of state-aided workshops. This socialist right to guaranteed employment was strongly opposed by critics, such as Alexis de Tocqueville, who feared state control of the entire economy. The right to work, however, was quickly accepted under capitalism as a right to the opportunity to access employment. In The Right to Work (1917), John Elliott Ross noted the need for the state to provide the opportunity of working for a decent wage, to create employment bureaus and a system of compulsory social insurance.

Despite opposing socialist and capitalist views about how to supply work, countries under different economic regimes agreed the need to recognize work as a human right in article 23 of the 1948 Universal Declaration of Human Rights. They agreed on one thing: people must work because work is valuable to both society and the individual. Today, the clash between socialism and capitalism has mostly vanished, but the debate continues about whether and to what extent states should intervene in order to provide enough work. This piece argues that the debate places too much emphasis on how to provide work although work can sometimes be meaningless, unwanted or even detrimental to society. The current debate about work overlooks the human potential to reduce the need to work.

\section{Beyond Socialism and Capitalism Work Dogma}

Paid work may be regarded by some as a valuable activity contributing to human flourishing or a source of identity, self-realization or fulfilment. However, for many, work is considered a rather repetitive and stressful activity and predominantly instrumentally valuable as a source of income. It is certainly income that is primarily demanded by most people through the right to work.

In his famous book Le Droit à la paresse (1880), Paul Lafargue considered the right to work to be a mental aberration. He reproached the working class for proclaiming it a revolutionary principle during the 1848 French Revolution, which he argued consolidated the dogma of work preached by Christian ethicists, political economists, and moralists. For him, workers should have instead proclaimed the right to be lazy and accustom themselves to working three hours a day, reserving the rest of the day and night for leisure and feasting. However, he did not say a word about how to achieve this goal or who would work to prepare the feast. 
Later, in his collection of essays In Praise of Idleness (1932), Bertrand Russell shared Lafargue's idea that far too much work was done in the world. He deplored capitalism for regarding the virtue of hard work to be an end in itself, forcing workers to produce things that are not wanted, whilst also criticising socialism for making people work on useless projects. Russell estimated that with modern technology and a moderate amount of sensible organization about four hours of work a day would be sufficient to meet basic necessities and the comforts of life, which he did not define. For the rest, people should use their time as they see fit.

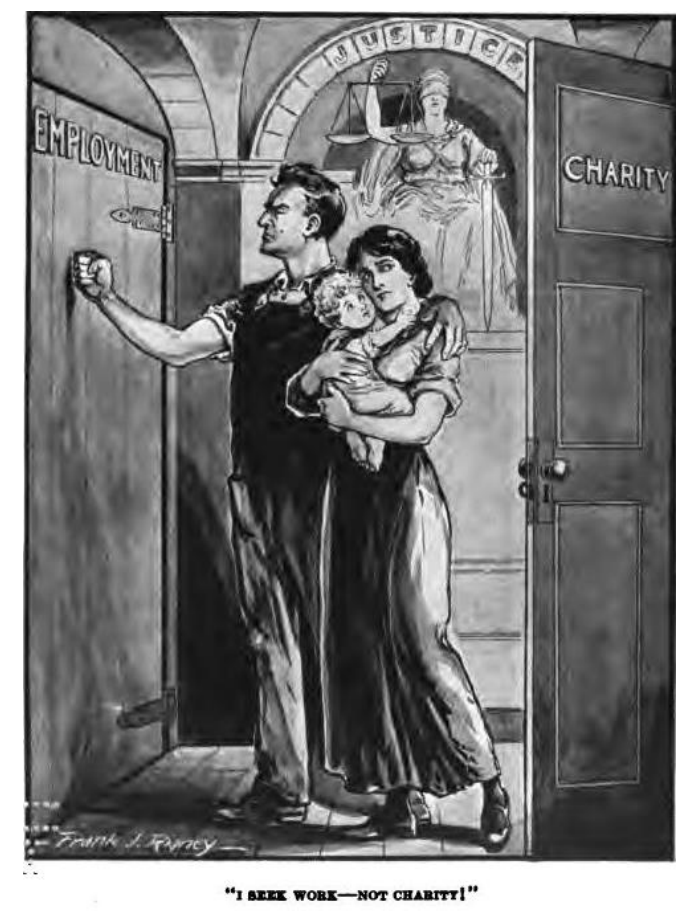

Source: John Elliott Ross, The Right to Work (1917)

Lafargue and Russell provocatively rejected the dogma of work underlying the arguments put forward by authors like Ross in The Right to Work. They presented 'laziness' or 'idleness' as being of greater value than work; work being only the means to achieve them. Working less, however, does not necessarily mean to be lazy or idle. It also means being free from an activity that some people would not freely do if they had the choice. A narrative of freedom, such as free time and free choice of employment, instead of laziness and idleness, would maybe have been more socially acceptable. This narrative of freedom underlines the human economy. Moving beyond the work dogma, the human economy framework proposed in this piece suggests that prior economic models overlooked the human potential that exists in society that could be used to increase freedom from work.

\section{Towards Freedom from Work in the Human Economy}


There is a debate about reducing working time without income loss. For example, in Métamorphoses du travail (1988), André Gorz discusses how technology can increase free time by reducing production time. However, he shows that free time induced by technology is unequally distributed. A section of the population, whose work becomes unnecessary due to technological change, is expelled from work. For Gorz, in our societies only a professional elite is able to increase their income and leisure time by getting their own personal tasks done for them, at low cost, by others. Beyond relying on technology, he suggested to plan the progressive and mandatory reduction of working time down to 1000 hours a year (20 hours a week in average). Loss of income should be compensated by a system of taxation. Gorz's solution to increase free time challenges the dogma of work, but not the essence of work. Work remains an activity carried out by human beings reduced to a form of capital producing economic value. The human economy framework asks instead, what if human beings where able to do more than create economic value?

The human economy challenges that human beings constitute a form of productive capital. Among influential economists such as Smith, Mill and Marx each analysed the function of human labour in the capitalist system of production. They examined human labour as productive capital, something Marx criticized in a systematic manner without denying completely. The metamorphosis of human beings into human capital was completed by the second half of the twentieth century as captured in Becker's Human Capital (1964). By oversimplifying human beings in the economic process of production, traditional economics has reduced human beings to one single function and skill: producing economic value. It is overlooking the potential of human beings.

Building upon Amartya Sen's idea of capabilities in Development as Freedom (1999), the human economy approach suggests that human beings do more than produce economic value. Through work, human beings also create valuable benefits for others such as health, food, education or housing. Some of these benefits are universally recognized as human rights. Within the human economy, these benefits recognized as universal human rights are called 'human benefits'. Under the current economic system on the contrary, these human benefits are only an unintended consequence of work; humans create human benefits through work mostly when they are economically profitable. Many people would probably find it meaningful to allocate their working time for the creation of human benefits if they had a choice by being rewarded for doing so, but the current system of employment mostly rewards the skill of producing economic value. As a result, a part of the human potential of creating human benefits that exists in the society is 
not used although some would be willing to use it. There is an overlooked human potential and this is the first observation of the human economy.

It happens that most human benefits, such as food, health, education, housing or living in a clean and safe environment are also why most people must get an income in the first place. Were they more efficiently created, for example by rethinking the purpose of technology or the way housing prices are determined, people would need to work less to access them and society's freedom from work could increase. This is the second observation of the human economy. It is already the case that the number of hours that people need to work has decreased in the last few decades, at least for most individuals in wealthier countries as Figure I shows. It is not accurate to say, however, that the current economic system is the most efficient economic system for expanding freedom from work for the simple reason that free time is not a recognized indicator of economic performance.

Figure I: Annual hours actually worked per worker in five industrialized countries (1950-2016)

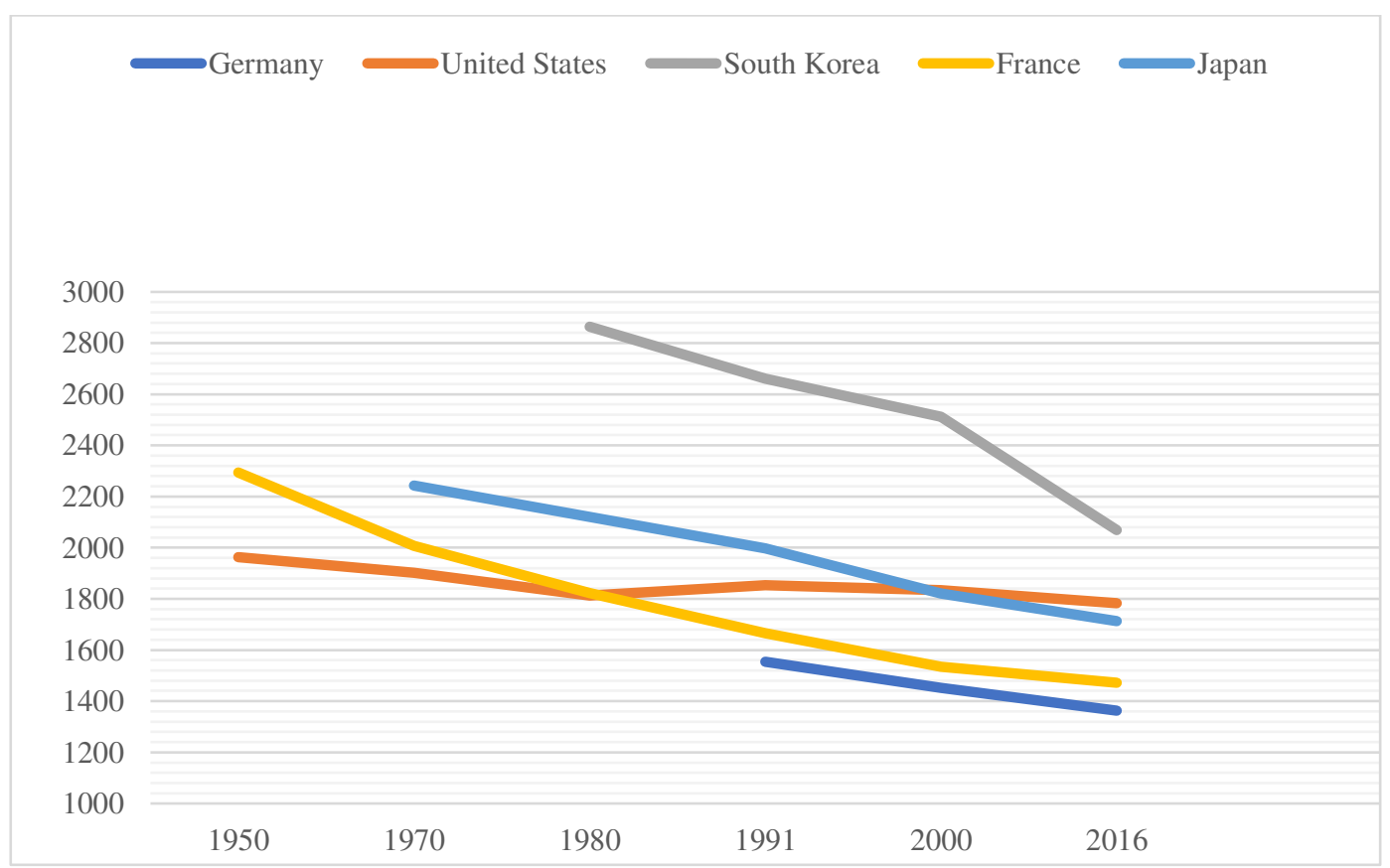

Source: OECD (2018), Hours worked (indicator). doi: 10.1787/47be1c78-en (Accessed on 15 February 2018)

Finally, creating human benefits more efficiently for some may also contribute to cause human costs for others and increase their own necessity to work. Indeed, presenting human beings as a form of capital not only blinds that human can create human benefits but also blinds the human costs sometimes caused by traditional work. This is the third observation of the human economy. For 
example, the use of pesticides may be considered as a technology to produce food more efficiently thereby increasing freedom from work for consumers of food produced with pesticides. However, pesticides cause at the same time human costs in terms of harm to human health or access to clean water for all. Additional, but avoidable, work must be supplied to remedy these human costs via medical treatment or environmental measures. This supplementary work has a cost. It is paid for individually by those affected or collectively by taxpayers on their income. For all of those who must pay for these remedial measures, the necessity to work increases. Table I summarizes the terminology of the human economy presented so far.

Table I: Definitional Framework of the Human Economy in Comparison to Capitalism.

\begin{tabular}{|l|l|l|}
\hline & Current economic system & Human Economy \\
\hline Agent and Power & Human Capital, Labor & $\begin{array}{l}\text { Human beings } \\
\text { Human potential }\end{array}$ \\
\hline Function of agents & Producers of goods and services & Creators of human benefits \\
\hline Rewarded skill & Economic productivity & Human creativity \\
\hline Output of work & Goods and services & $\begin{array}{l}\text { Human benefits } \\
\text { Human costs }\end{array}$ \\
\hline $\begin{array}{l}\text { Purpose of the } \\
\text { economic system }\end{array}$ & $\begin{array}{l}\text { Economic Growth } \\
\text { Material Security } \\
\text { Full-Employment }\end{array}$ & $\begin{array}{l}\text { Securing human benefits } \\
\text { Increasing freedom from work }\end{array}$ \\
\hline
\end{tabular}

Source: Nicolas Bueno, 'From the Right to Work to Freedom from Work: Introduction to the Human Economy' 33(4) IJCL (2017) 484.

The article concludes that by focusing on the overlooked human potential and the impact of human costs on the need to work, it may be possible to increase freedom from work whilst simultaneously securing a wide range of human benefits. To increase freedom from work and secure human benefits, however, there is a need to better understand why people work and analyse more carefully what people create and destroy through traditional paid work. The notions of economic productivity and human capital must be rethought.

\section{Main References:}

Ascoli, Max. 'The Right to Work.' Social Research 6 (1939): 255-268. 
Autor, David, 'Why Are there still so many Jobs? The History and Future of Workplace Automation.' Journal of Economic Perspectives 29(3) (2015): 3-30.

Balakrishnan, Radhika, James Heintz and Diane Elson. Rethinking Economic Policy for Social Justice: The Radical Potential of Human Rights. London: Routledge, 2016.

Becker, Gary. Human Capital. $3^{\text {d }}$ ed., Chicago: University of Chicago Press, 1993.

Blanc, Louis. Le socialisme: Droit au travail. $3^{\mathrm{d}}$ ed., Paris: Aux Bureaux du Nouveau Monde, 1849.

Bueno, Nicolas. 'From the Right to Work to Freedom from Work: Introduction to the Human Economy.' International Journal of Comparative Labour Law and Industrial Relations 33(4) (2017): 463-487.

Bueno, Nicolas. 'Should we Have a New Human Right to Freedom from Work?' Latest Thinking Video, https://doi.org/10.21036/LTPUB10720

Frayne, David. The Refusal of Work: The Theory and Practice of Resistance to Work. London: Zed Books, 2015.

Gorz, André. Critique of Economic Reason. Translated by Gillian Handyside and Chris Turner, London: Verso, 1989.

Lafargue, Paul. The Right to Be Lazy: Being a Refutation of the "Right to Work" of 1848. Translated by Harriet E. Lothrop. Standard Publishing, 1904.

Marx, Karl. Capital: A Critique of Political Economy, Vol. 1. Reprint in Karl Marx and Frederick Engels: Collected Works 35, Progress Publ., 1996.

Rifkin, Jeremy. The End of Work: The Decline of the Global Labor Force and the Dawn of the Post-Market Era. Putnam, 1995.

Ross, John E., The Right to Work. New York: The Devin-Adair Company, 1917.

Russell, Bertrand. In Praise of Idleness: And Other Essay. $3^{\mathrm{a}}$ impr., Allen and Unwin, 1936.

Sarkin-Hughes, Jeremy and Mark Koenig. "Developing the Right to Work: Intersection and Dialoguing Human Rights and Economic Policy.", Human Rights Quarterly 33 (2011): 133.

Sen, Amartya. Development as Freedom. Oxford: Oxford University Press, 2001.

Weiss, Yoram. 'Work and Leisure: A History of Ideas.' Journal of Labor Economics 27 (2009): 120.

\section{For citation:}

$\mathrm{N}$ Bueno, Introduction to the Human Economy, SPEAK OUT at The Laboratory for Advanced Research on the Global Economy, Centre for the Study of Human Rights, LSE (August 2018). 